\title{
A CORRELATION STUDY BETWEEN STUDENTS' PERCEPTION ON TEACHERS' PERFORMANCE IN TEACHING ENGLISH AND THEIR ACHIEVEMENT
}

\author{
Imelda Effendie ${ }^{1}$, Samsul Amri ${ }^{2}$, Melda Yeni ${ }^{3}$ \\ English Study Program \\ Universitas Islam Indragiri - Tembilahan ${ }^{1,2,3}$
}

\begin{abstract}
A B S T R A C T
The main purpose of this study is to find out the correlation between the students' perception of teacher's performance and their achievement at eleventh-grade students of SMK N 1 Kempas. The research design is a correlation study and used a simple total sampling technique in determining the sample. The total of the population was 146 students and amount of sample are 70 students. The data were collected by using a questionnaire for students' perceptions and documentation for students' achievement. The indicators of measurement for students' perception are intelligence, behavior, dressing style, friendliness, and authority, body movement, facial expression, vocal intonation, and achievement. Whereas the indicators of students' achievement are a cognitive domain, affective domain, and psychomotor domain. From the analysis of the result, out of 70 students filling the questionnaire, the students' mean score for students' perception of teacher's performance at eleventh-grade students of SMK N 1 Kempas was 79.8 at Good level. Whereas the students' mean score for their achievement at eleventh-grade students of SMK N 1 Kempas was 82.1 at a Good level. For the correlation value, the researcher got $r$ coefficient of 0.868 , which is classified as a high level. For hypothesis testing, the researcher got $r_{\text {calculated }}(0.868)$ is higher than $r$ table $(1 \%=0.249$ and $5 \%=0.238)$. Therefore Ho is rejected and $\mathrm{Ha}$ is accepted. It implies there is a significant and positive correlation between students' perception of teachers' teaching performance and their achievement at eleventh-grade students of SMK N 1 Kempas.
\end{abstract}

Keywords: Students'Perception, Teachers' performance, Students' Achievement

\section{INTRODUCTION}

A teacher is a role model for his or her students in front of the class. In studying in the class, students will focus on what their teacher looks like, what the teacher brings in the class or what the teacher's method of teaching. The quality of the teacher is one of the important factors to make students become more spirit in learning. In this case, the teacher's cover can influence the students' achievement. The teacher's cover includes the performance of the teacher in teaching. 
Hammond (2010:12) said that developing teacher effectiveness is as important as measuring it. Many studies have concluded that teachers' participation in standardsbased performance assessments can help teachers improve their practice. It means that asses the teachers' performance is important for the teacher's improvement in teaching. The ones who can measure the teacher well are the students, based on their perception.

Students' perceptions can be good or not. As usual, the mood of students in learning is different from each other. Their perception toward the teacher's performance can be impacted by their motivation in learning and their achievement in the study. In this case, the main case is in English subject.

The previous researches findings have proven that students' perceptions of the teachers' activities have been an interesting issue to be investigated, for instance, Donahue (1994) conducted the study was about students' perceptions of their teachers, their school, and themselves as learners. The results showed that both males and females have good critical thinking ability and perform equally well when given tasks that require these skills.

The researcher has reviewed other researches title which connected with the research was conducted. First, the writer is Wade Clay Smith. 1998. The title is “Students' Perceptions of Their Biology Teachers' Interpersonal Teaching Behaviors and Students' Achievement and Affective Learning Outcome" from Texas Tech University. Second is a dissertation from Nur Azizah Karimah. 2014. The title "Teaching Act Performance Its Solutions for Second Grade Students of SDLB E Bhina Putera Surakarta in 2013/2014 Academic Year", from Faculty of Islamic Studies Muhammadiyah, University of Surakarta. Based on research and analysis of data that researchers do about the problems in teaching prayer movement in second-grade students of SDLB E Bhina Putera Surakarta, the authors conclude from the students, curriculum, facilities and infrastructure, and environment.

In this study, the researcher will focus on finding out the correlation between teachers' performance in teaching English and the tenth students' achievements of SMK N 1 Kempas. Teachers and students cannot be separated because they are the causal of the learning process. Also, the teacher's performance and the students' achievement is having a connection. The students' achievement can be definite for students' study results. 
Based on the statement above, that teacher's performance and students' achievement has a connection to each other. Through the exact and comfortable teacher's performance can give a good or bad effect on the result of the students. Based on the background above, the researcher decides to research with the main purposes to find out the students' perception of the teachers' performance in teaching, to find out the students' achievement in English, and to find out if there is a positive correlation between students' perception of teachers' performance in teaching English and their achievement in learning English.

\section{LITERATURE REVIEW}

\section{Concept of Teachers' Performance}

According to Hammond (2010:5) "Performance is what teachers do in the classroom, and which are related to later teacher effectiveness, are a much more potent tool for evaluating teachers' competence and readiness, as well as for supporting needed changes in teacher education".

Leigh and Mead (2005) in Chamundeswari (2006:2) bring about the fact that the quality of teaching has come down gradually world over, demonstrate that the skills of teachers have come down due to outdated preparation on the part of the teacher and stagnant compensation schemes by the management of the educational institution.

Based on Ginting (2009:11) "There are some indicators that the researcher put in this research, they are intelligence, behavior, dressing style, friendliness and Authority, body movement, facial expression, vocal intonation, and achievement."

1. Intelligence

Intelligence is a good ability in learning, understanding and giving a reason about something (knowledge). A teacher is demanded to understand property everything and can give and answer a question to the students.

\section{Behavior}

Behavior is the way of behaving. It is something that we can see from someone in daily. And it is one of factor someone can be like or disliked. As the way of behaving, good or bad behavior appears in the way of thinking and speaking. Wubbels (1985) in Smith (1998:31) tells "behavior that refers to the relationship 
between the teacher and his students and which is expressed in the interaction between the personal communications in the classroom."

\section{Dressing Style}

For a teacher, dressing style is a part of their performance. It is natty or not. It does not show whether a teacher is from a high economy or low economy-level family, but it is very important for a teacher to show she is well educated or not.

\section{Friendliness and Authority}

Friendliness is an act of being friendly whereas authority is an ability, a power or a right to influence, to control and to command other people.

\section{Body Movement}

Body movement or body language is part of communication. It is a non-verbal language, which is very largely used by people in communicating their ideas, feeling or intentions. When the teacher has good body movement, it will give a good message to his/her students.

\section{Facial Expression}

Facial expression is a nonverbal statement that we can see from someone's face. There is some part on one's face as a clue of expressions, they are eyes, forehead, lips, and chin. Based on Allan in Ginting (2009:18) said that eyes may be the most visible and accurate cues human communication movement since eyes are a pound of focus.

7. Vocal Intonation

When the teacher speaks, vocal intonation is one of the primes in the teacher's performance. It is an interesting factor in the learning process. There is the time when it's funny, angry and for instance.

8. Achievement

Achievement is the final result of teaching. The teacher can be said as a good teacher if he/she can bring the students also good at learning.

\section{Concept of Teaching}

Based on Chamundeswari (2006:1) teaching is a highly noble profession and teachers are always a boon to society. The teaching acts of a teacher are meant to instill 
confidence in the youth so that not only while as students but also throughout their lifetime they could acquire relevant knowledge whenever they need it.

Mahmud in Ginting (2009:21) said that in teaching a teacher is not only asked to concern the materials and method of teaching, also concern how to draw students' attention to the lesson.

The similar statement comes from Saud (2009:55) Teaching is the process of sending the knowledge. It is a complex activity; they are the integrated skill to send the message, information, lesson, or knowledge.

\section{Concepts of Students' Achievement}

In the Standards for test construction (APA, 1999) in Algarabel \& Carmen (2001:44) achievement is viewed basically as the competence a person has in the area of content. This competence is the result of many intellectual and nonintellectual variables. The scientific study of achievement encompasses data coming from experiments with word lists as well as from the acquisition of complex domains, like computer programming, mathematics, or how people solve physics problems. At the experimental level, the achievement is referred to as acquisition, learning, or knowledge representation, sometimes depending on theoretical biases.

Based on Hattie (2009) in Huitt (2009:3) there are some factors related to school achievement identified in the figure include the characteristics of the teachers and students before they enter the classroom. The first is most interest in teacher training programs. The second is more interest in schools. The last is the teachers' expectations.

There are three domains in evaluating based on Hamalik (1994:79). They are cognitive, affective and psychomotor domains.

The cognitive domain is changing that concert with the increase of knowledge and that synthesize. The parts of cognitive domains are 1) Knowledge. Knowledge is a reminder of the material of learning from the fact to theories. 2) Understanding. Understanding is the ability to understand and master the meaning. 3) Application. Application is an ability to use or to apply what the materials are, in a factual situation. 4) Analysis. The analysis is to find out the structural organization of the learning material. 5) Synthesis. Synthesis is the ability to combine the different structures of 
material to be one conclusion. 6) Evaluation. Evaluation is the ability to value something based on the criteria.

The affective domain is a change that influences the behavior or attitude of students. This domain makes students aware of new values. The parts of Affective domains are: 1) Receiving. Receiving is the condition where someone wants to receive and pleasure about it. 2) Responding. Responding is the open-minded of someone about one condition. 3) Valuing. Valuing is receiving the value and how important it is. 4) Organization. The organization is conceptualization about a value. 5) Characteristic. Characteristic is the formation of valuation.

The psychomotor domain gives students perceptual skill and motor skills. Based on Singer in Hamalik (1994:852) the part of Psychomotor domains is 1) Contacting, manipulating, and/or moving an object. 2) Controlling the body or object, as in balancing. 3) Moving and/or controlling the body or parts of the body in space in a brief timed act or sequence under predictable and/or unpredictable conditions. 4) Making controlled, appropriate sequential movements (not time-restricted) in a predictable and/or unpredictable and changing situation.

\section{The Relationship between Teachers' Performance in Teaching and Students' Achievement}

Soar (1968) in Smith (1998:18) found evidence of a curvilinear relationship between teaching styles and lower cognitive pupil outcomes, with both extreme indirect and direct teaching styles being related to lower cognitive outcomes, but the mixed teaching style was related with higher cognitive outcomes. There was also evidence of a linear relationship between indirect teaching style and higher-level cognition in the students. There was a modest relationship (exact statistic was not reported by Soar) between indirect teachers and students with low anxiety levels, for any other type of student there was not a significant relationship between teaching style and student achievement. Student perceptions of their teacher's interpersonal teaching behaviors are instrumental in effecting student cognitive and affective learning outcomes. 


\section{RESEARCH METHOD}

This research is designed as a correlational inquiry. Creswell (2005:52) said that correlation designs are procedures in quantitative research in which investigators measure the degree of association (or relationship) between two or more variables using the statistical procedure of correlation analysis. Moreover, the research was conducted at SMK N Kempas Kabupaten Indragiri Hilir in 2017.

Additionally, Sugiyono (2010:117) asserts that the population is the generalization area consist of objects or subjects who have a certain quality and characteristics valued by the researcher to be observed and then take the hypothesis or conclusion. In this research, the population is all second-year students of SMK N 1 Kempas.

Table 1. The population of the Research

\begin{tabular}{|c|l|c|}
\hline No & \multicolumn{1}{|c|}{ Class } & Amount of Students \\
\hline 1 & Accounting & 30 \\
\hline 2 & Engineering of Building Draw & 26 \\
\hline 3 & Network Computer Technique & 23 \\
\hline 4 & Motorcycle Technique & 34 \\
\hline 5 & Engineering of Aqua Culture & 9 \\
\hline 6 & Agribusiness of Agricultural Crops & 15 \\
\hline 7 & Agribusiness of Agricultural Crops Horticultural & 15 \\
\hline \multicolumn{2}{|c|}{ Total } & 146 \\
\hline
\end{tabular}

The sample is part of the value of the population (Sugiyono, 2010:118). The sampling technique in this research uses a simple random sampling technique. Sugiyono (2010:120) asserts about the random sampling method that takes the samples randomly without care about the degree of objects of the population.

The research instrument is used to measure something called the research variable. The researcher uses the Likert scale for the questionnaire. Sugiyono (2010:134) said that the Likert scale is the scale used by someone in the questionnaire to measure the attitude, opinion, and perception about something. For the questionnaire, the indicators that the researcher shows up are like the table below (Ginting (2009:11):

Table 2 Grills of Instrument

\begin{tabular}{|c|l|c|}
\hline Variable & \multicolumn{1}{|c|}{ Sub-Variable } & Number of Items \\
\hline & 1. intelligence, & 3 \\
& 2. behavior, & 2 \\
& 3. dressing style, & 2 \\
Teachers' performance & 4. friendliness, & 2 \\
& 5. body movement, & 3 \\
& 6. facial expression, & 2 \\
& 7. vocal intonation and & 3 \\
\hline
\end{tabular}




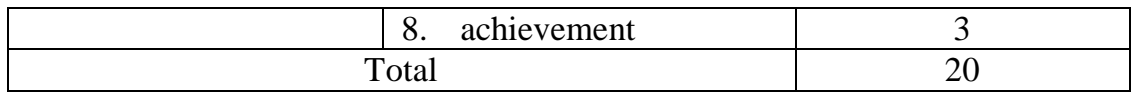

Data collection techniques are part of data collection instruments that determine the success or failure of research. Therefore, to obtain accurate data in this study the researchers used a technique of data collection field study. In this field study, the authors aimed directly to research the location or object that has been determined. Field studies pursued in the following ways: with questionnaires and observation.

Sugiyono (2010:199) said that the questionnaire is the data collecting technique that gives respondents some questions list to measure or survey the variable that someone thorough.

In this study, the data analysis techniques used are quantitative analysis techniques with a qualitative approach that describes the results of the study as it is. The data have been obtained from the results of field studies that are then collected and processed and analyzed by describing, explaining and commenting and calculating using a single table to show the actual state of facts that occurred in the field. There are three research instruments that the researcher applied observation, interview, and questionnaire.

In calculating the percentage of indicators using the following formula:

$P=\frac{F}{N} x 100 \%$

Explanation:

$\mathrm{P} \quad=\quad$ Percentage

$\mathrm{F} \quad=\quad$ Frequency

$\mathrm{N}=$ Total

(Sudijono, 2010:43)

After doing the test, reading, and writing. The writer would like to find out the correlation coefficient between those skills. To find it, the product-moment formula that the writer uses is:

$r_{x y}=\frac{\sum x y}{\sqrt{\left(\sum x^{2}\right)\left(\sum y^{2}\right)}}$

Explanation:

$r \quad$ : correlation figures $\quad x \quad:(\mathrm{X}-\mathrm{X})^{2}$ for reading

$y \quad:(Y-Y)^{2}$ for writing $\sum x y \quad$ : sigma of $x$ and $y$

Arikunto (2010:273) 
Below is the interpretation of the $r$ value:

Table $3 r$ Coefficient Interpretation

\begin{tabular}{|c|c|}
\hline Coefficient Correlation & Class \\
\hline $0.800-1.00$ & High \\
\hline $0.600-0.800$ & Enough \\
\hline $0.400-0.600$ & Low Enough \\
\hline $0.200-0.400$ & Low \\
\hline $0.000-0.200$ & Very Low (No Correlation) \\
\hline
\end{tabular}

There are two hypotheses in this research; they are work hypothesis (Ha) and the Null hypothesis (Ho). If $r_{\text {calculuted }} \leq r_{\text {table }}$ then Ho accepted but if $r_{\text {calculuted }} \geq r_{\text {table }}$ then Ho rejected. If Ho rejected means that there is a significant correlation from those skills. The other way, to know the correlation we can interpret based on the value of $r$ coefficients and see on the table above.

a. Work hypothesis (Ha) $:(r \neq 0)$

There is a significant correlation between students' perception of teacher's performance in teaching English and students' achievement.

b. Null hypothesis $(\mathrm{H} 0):(r=0)$

There is no significant correlation between students' perception of teacher's performance in teaching English and students' achievement.

\section{FINDINGS AND DISCUSSION}

This study purposes to find out the correlation between students' perception of the teachers' performance in teaching toward their learning achievement. It was carried out at SMK Negeri 1 Kempas. The results of the data could be presented as below:

\section{Students' Perception of Teachers' Teaching Performance}

The researcher distributed the questionnaire to the 70 students. She has selected students' scores in the questionnaire. There are eight indicators to measure the teachers' performance in teaching; intelligent, behavior, dressing style, friendliness, body movement, facial expression, vocal intonation, and achievement. The results could be seen as follow: 
Table 4 Students' Perception of Teachers' Teaching Performance

\begin{tabular}{|c|c|c|c|c|c|}
\hline No. & Interval Scale & Category & $\mathrm{F}$ & Percentage $(\%)$ & Average \\
\hline 1 & $80-100$ & Very Good & 35 & 50 & \multirow{5}{*}{79.8} \\
\hline 2 & $70-79$ & Good & 30 & 43 & \\
\hline 3 & $60-69$ & Enough & 5 & 7 & \\
\hline 4 & $50-59$ & Low & 0 & 0 & \\
\hline 5 & $00-49$ & Very Low & 0 & 0 & \\
\hline \multicolumn{3}{|c|}{ Total } & 70 & $100 \%$ & Good \\
\hline
\end{tabular}

Dealing with the data above, it could be seen that the students' perception of the teachers' teaching performance. There are 35 students (50\%) of the students who have a very good perception of their teachers' teaching performance. Then there are 30 students (42\%) of the students who have good perception. Meanwhile, only 5 students (7\%) have enough perception of their teachers' teaching performance. Moreover, the mean score has shown that their perception was at a good level (79.8). It could be implied that the teachers' have good teaching performance which covers eight points intelligent, behavior, dressing style, friendliness, body movement, facial expression, vocal intonation, and achievement.

\section{Students' Achievement}

In collecting the data, the researcher took the documentary of the students' English semester score test. There are 70 students as the samples of the study. The results are below:

Table 5 Students' English Achievement

\begin{tabular}{|c|c|c|c|c|c|}
\hline No. & Interval Scale & Category & F & Percentage (\%) & Average \\
\hline 1 & $80-100$ & Very Good & 45 & 64 & \\
\cline { 1 - 5 } 2 & $70-79$ & Good & 25 & 36 & \multirow{2}{*}{82.1} \\
\hline 3 & $60-69$ & Enough & 0 & 0 & \\
\hline 4 & $50-59$ & Low & 0 & 0 & \multirow{2}{*}{ Very Good } \\
\hline 5 & $00-49$ & Very Low & 0 & 0 & $100 \%$ \\
\cline { 1 - 4 }
\end{tabular}

Based on the table, it could be proven that the students' English achievement. There are 45 students $(64 \%)$ of the students have very good achievement in English. Moreover, there are 25 students $(36 \%)$ of the students who have good English achievement. Meanwhile, none of the students who have enough, low and very low category. Then the mean score has informed that their English achievement was at a very good level (82.1). It could be implied that the students have sufficient English achievement which includes four language skills and components. 


\section{Normality and Reliability Testing}

To gain accurate result the data must be distributed normally and reliable, to find the goal the researcher utilized the SPSS 17 program, and then the results are as follow:

Table 6 Reliability Statistics

\begin{tabular}{|c|c|}
\hline Cronbach's Alpha & N of Items \\
\hline .903 & 2 \\
\hline
\end{tabular}

The table shows that the Cronbach's Alpha score is 0.903. It means that the score is higher than 0.60 . $(0.903>0.60)$, in other words, the data was reliable.

Table 7 Normality Testing

\begin{tabular}{|l|r|r|}
\hline & $\begin{array}{c}\text { Students' } \\
\text { Perception }\end{array}$ & $\begin{array}{c}\text { Students' English } \\
\text { Achievement }\end{array}$ \\
\hline $\mathrm{N} \quad$ Valid & 70 & 70 \\
$\quad$ Missing & 0 & 0 \\
Skewness & -.106 & .490 \\
Std. Error of Skewness & .287 & .287 \\
\hline
\end{tabular}

The researcher used the Skewness analysis to gain normality data. The data are categorized as normal if the score of Skewness divided by the Std. Error of Skewness is in the interval score -2 to 2 . Dealing the data above, it could be found that the students' perception data was $(-0.106: 0.287=-0.369)$, and then the data of students' English achievement was $(0.490: 0.287=1.707)$. It could be implied that the data were distributed normally since the result of the analysis in the interval score -2 to 2 .

\section{Correlation between the Students' Perception of the Teachers' Teaching Performance and their Achievement}

After analyzing the students' perception of their teachers' teaching performance and their achievement, the researcher analyzed the data to gain whether or not there is a positive correlation between two variables observed. The data were analyzed by using SPPS 17; it is expected to gain more precise and fixed results. The data were in the following: 
Table 6 Correlation between Students' Perception of Teachers' Teaching Performance and their Achievement

\begin{tabular}{|ll|c|c|}
\hline & $\begin{array}{c}\text { Students' } \\
\text { Perception }\end{array}$ & $\begin{array}{c}\text { Students' English } \\
\text { Achievement }\end{array}$ \\
\hline Students' Perception & Pearson Correlation & 1 & .868 \\
& Sig. (2-tailed) & & .000 \\
\hline Students' English & Pearson Correlation & .868 & 1 \\
Achievement & Sig. (2-tailed) & .000 & \\
\hline
\end{tabular}

a. Listwise $\mathrm{N}=70$

Concerning the analysis above, it can be found that the result of the Coefficient Correlation of Pearson Product Moment between two variables. The score is 0.868 , which is categorized as a very high correlation. The researchers analyzed with Ha: $\mathbf{r}_{x y} \neq 0$ and Ho: $r_{x y}$ $=0$. The score probability 0.05 then sig 0.01 . So $0.05 \geq 0.01$. Additionally, by using manual analysis it found that $\mathrm{r}_{\text {calculated }} 0.868$ then $\mathrm{rtable}(1 \%=0.249$ and $5 \%=0.238)$, so rcalculated $>$ rtable. Therefore, $\mathrm{Ha}$ is accepted and Ho is rejected. It means there is a significant correlation between students' perception of the teachers' teaching performance and their English achievement for the second year students of SMK Negeri 1 Kempas.

\section{CONCLUSION}

The researcher concluded that in general there is a significant correlation between students' perception of teachers' teaching performance and their achievement at second-year students of SMK N 1 Kempas. It was gotten from the value of $r$ coefficient 0.868 (high level). Then after hypothesis testing, the researcher found that both the variables investigated have a positive correlation. It can be implied that if the students have a positive perception of their teachers' teaching performance then they have positive results in learning.

Based on the conclusion above, the researcher would like to offer some suggestions to be considered to help students master English especially in recount text mater: Firstly, it is suggested for the students to increase the motivation in learning not only from the teacher's performance or style in teaching. Secondly, for the teacher also to be better in teaching and have a good manner and attitude, method and the cover in teaching to be a good teacher. Thirdly, it is expected for the other researchers to be better in researching correlation design focus. 


\section{REFERENCES}

Arikunto, Suharsimi. (2004). Evaluasi Program Pendidikan. Jakarta: Bumi Aksara.

Algarabel, Salvador and Carmen Dasi. (2001). The Definition of Achievement and the Construction of Texts for Its Measurement: A Review of the Main Trends. Seccion De Metodologia, Psicologia. Vol (22) 43-46, University of Valencia, Spain.

Chamundeswari, S. (2008). Job Satisfaction and Performance of School Teachers.

Chapmar, Marilyin. (2000). The Primary Program. A Framework for Teaching. British Columbia: Ministry of Education.

Creswell, John, W. (2005). Educational Research Planning, Conducting, and Evaluating: Quantitative and Qualitative Research $\left(2^{\text {nd }} E d\right)$. New Jersey: Pearson Education International.

Donahue, Janice Marie. (1994). Students' Perception of their Teachers, their School, and Themselves as learners. Professional Studies in Education, Education (Educational Administration) of Lowa State University. Ames, Lowa.

Ginting, Andevi. (2009). The Correlation between Teachers' Performance in Teaching English and the Twelfth Students' Achievements of Madrasah Aliyah Nurul Huda Selesai. Binjai: STKIP.

Hamalik. Oemar. (1994). Kurikulum dan Pembelajaran. Bandung: Bumi Aksara.

Hammond, Linda Darling. (2010). Evaluating Teachers Effectiveness: How Teacher Performance Assessment can Measure and Improve Teaching. Washington DC: Center of American Progress.

Hasan, Iqbal. (2004). Analisis Data Penelitian dengan Statistika. Jakarta: Bumi Aksara.

Heaton, J.B. (2010). Writing English Language Test (New Edition): Longman

Huitt, William G, et.al. (2009). A System-Based Synthesis of Research Related to Improving Students Academic Performance. Athens Institute for Education and Research (ATINER), Athena.

Karimah, Nur Azizah. (2014). Teaching Act Performance Its Solution for Second Grade Students of SDLB E Bhina Putera Surakarta in 2013/2014 Academic Year. Faculty of the Islamic Studies Muhammdiyah University of Surakarta.

Smith, Wade Clay. (1998). Students' Perception of their Biology Teachers' Interpersonal Teaching Behavior and Students Achievement and Affective Learning Outcome. Texas Tech University. 
Sudijono, Anas. (2009). Pengantar Evaluasi Pendidikan. Jakarta: Rajawali Press

Sugiono. (2010). Metode Penelitian Pendidikan, Pendekatan Kuantitatif, Kualitatif dan $R \& D$. Bandung: Alfabeta. 